\title{
Storage protein variability in natural populations of maté (Ilex paraguariensis) in Brazil
}

\author{
Tatiana Schäffer Gregianini ${ }^{*}$ iD Helga Winge ${ }^{2}$
}

12aboratório Central da Secretaria de Saúde do Estado do Rio Grande do Sul (LACEN/SES-RS), 90610-000, Porto Alegre, RS, Brasil. E-mail:
tatiana-gregianini@saude.rs.gov.br. "Corresponding author. ${ }^{2}$ Departamento de Genética, Universidade Federal do Rio Grande do Sul (UFRGS), Porto Alegre, RS, Brasil.

ABSTRACT: Samples of 168 maté trees (Ilex paraguariensis) from four natural populations of different states of Brazil (Rio Grande do Sul, Santa Catarina, Paraná and Mato Grosso do Sul) were analyzed for their variability in storage proteins seed, which were used to estimate the degree of differentiation among and within species, because are relatively stable during evolution. Data on band presence/absence from 80 different polypeptides were used to perform similarity coefficient of Jaccard. A high level of genetic variability was reported within sampled populations $\left(S_{\text {I }}\right.$ intra $\left.=0.374\right)$. Lower levels of diversity were observed between populations $\left(S_{J}\right.$ inter $\left.=0.308\right)$. Total genetic diversity of maté was $H_{s p}=0.264$ estimated by Shannon measure. Partition of that value disclosed that $95 \%$ of the total diversity is within-population, and only $5 \%$ to between-populations. The phenogram based on King's distances indicates a certain degree of geographic differentiation. This represents the first study on storage protein variability in I. paraguariensis and guides the choice of the specimens to increment germoplasm banks and genetic improvement programs.

Key words: 'chimarrão', germoplasm banks, population genetics.

Variabilidade de proteínas de reserva em populações naturais de erva-mate (Ilex paraguariensis) no Brasil

RESUMO: A variabilidade de proteinas de reserva das sementes foi analisada em 168 árvores de quatro populações naturais de erva-mate (Ilex paraguariensis) dos estados brasileiros Rio Grande do Sul, Santa Catarina, Paraná e Mato Grosso do Sul. Estes marcadores foram utilizados para estimar o grau de diferenciação entre e dentro da espécie porque são relativamente estáveis ao longo da evolução. Dados sobre presença e ausência de bandas de 80 diferentes polipeptídios foram utilizados para calcular o coeficiente de similaridade de Jaccard. Encontramos alto grau de variabilidade genética dentro de cada uma das quatro populações de árvores $\left(S_{J}\right.$ intra=0.374). Menores níveis de diversidade foram observados entre as populações $\left(S_{J}\right.$ inter $\left.=0.308\right)$. A diversidade total da espécie Ilex foi $H_{s p}=0,264$, estimada pela medida de Shannon. A partição deste valor revelou que $95 \%$ da diversidade total é intrapopulacional, enquanto somente $5 \%$ é entre populações. $O$ fenograma, baseado nas distâncias de King, indica certo grau de diferenciação geográfica. Este trabalho representa o primeiro estudo de variabilidade em proteinas de reserva de I. paraguariensis e pode ser utilizado para orientar a escolha de espécimes para compor bancos de germoplasma e programas de melhoramento genético da espécie.

Palavras-chave: bancos de germoplasma, chimarrão, erva-mate, genética de populações.

\section{INTRODUCTION}

Ilex paraguariensis is a native tree from South America, occurring in Brazil, Paraguay, Argentina and in spots in Uruguay (GRONDONA, 1954). The leaves are currently used for stimulating drinks "chimarrão" (hot infusion) and "tererê" (cold infusion), canned and bottled beverages and soluble teas. Maté stimulates the central nervous system due to its xantines, such as caffeine and theobromine, acting as anti-inflammatory, antirheumatic, diuretic, appetite moderator, decreases total cholesterol and LDL-C, and blood glucose, and may also have potential antiobesity effect, potential anticonvulsant and antioxidant effects (GOSMANN et al., 1989, RICCO et al., 1995,
GUGLIUCCI \& STAHL, 1995, GUGLIUCCI, 1996, GOLDENBERG, 2002, FAGUNDES et al., 2015). I. paraguariensis extracts acts in the antidepressant process, presents antimutagenic effect on yeast cell populations (BRACESCO et al., 2003), on cancer cell proliferation (GONZALEZ DE MEJIA et al., 2005), have cardioprotective effects in rats (SCHINELLA et al., 2005) and antimicrobial in vitro against Escherichia coli and Proteus mirabilis (COSTA et al., 2017).

Cultivation of maté still faces many technical problems, mainly attribute to a lack of information on its biology, including genetic variability of the species. Most of information refers to seedling management, tree pruning, diseases, and industrial processing. 
Seed storage proteins were studied in many species for providing a suitable biological system for evolutionary studies. These patterns can be used to estimate the degree of differentiation among species or to evaluate individual differences within species (SINGH et al., 1994), mainly because they are relatively stable during evolution and only slightly influenced by environmental conditions and/or seasonal fluctuations (MCDANIEL, 1970, SINGH, 1991).

This paper aimed to analyze the genetic variability of four native populations of maté from Mato Grosso do Sul (MS), Paraná (PR), Santa Catarina (SC) and Rio Grande do Sul (RS) States, Brazil, distributed towards a northwestern/southeastern geographic transect, and evaluate the degree of genetic differentiation among these populations based on their patterns of seed storage proteins. This is the first time that storage proteins of I. paraguariensis were studied and little is known about their genetic variability.

\section{MATERIALS AND METHODS}

Plant material - The contents of individual seeds (embryo and endosperm) of 168 native trees of I. paraguariensis were analyzed (49 MS, 39 PR, $39 \mathrm{SC}$ and $41 \mathrm{RS}$ ), whose locations and geographic coordinates are shown in figure 1 . The pattern of storage proteins of only one seed was analyzed representing each native tree. The four populations are, respectively, about 360, 180 and $200 \mathrm{~km}$ apart. Ripe fruits were collected in February-March, 1997 and also in February-March, 1998 for RS. The trees were in loco labeled with numbered metallic plates for future harvests. Their geographic positions were recorded through a Global Position System. A control was made using a freeze-dried extract of 160 seeds (from pink fruits - not completely ripened) of one tree. This control provided the reference pattern used to adjust eventual migration distortions to optimize the comparisons among identical bands in the gel and also to allow correct comparisons among gels.

Protein extraction - The endosperm was frozen in liquid nitrogen, ground and the protein were extracted with $30 \mu \mathrm{L}$ of reduction buffer: $10 \mathrm{~mL} \mathrm{NaCl}$ $0.5 \mathrm{M}, \mathrm{pH} 2.4 ; 5 \mathrm{~mL}$ Tris-HCl $1.25 \mathrm{M}, \mathrm{pH} 6.8 ; 20 \mu \mathrm{L}$ EDTA 0.5M, pH 8.0; $1 \mathrm{~mL}$ SDS $20 \% ; 100 \mu \mathrm{L} 0.61 \%$ 2- $\beta$-Mercaptoethanol (w/v); $40 \mu \mathrm{L}$ Bromophenol Blue 2\% (Dr. DAVID H. MOON, personal communication). The extract was shaken for $1 \mathrm{~min}$ in a vortex and left overnight at $4^{\circ} \mathrm{C}$. Samples were then incubated for $10 \mathrm{~min}$ at $100^{\circ} \mathrm{C}$ in a water-bath and centrifuged at $14,000 \mathrm{rpm}$ for $15 \mathrm{~min}$. The supernatant was collected and stored at $5^{\circ} \mathrm{C}$ until analysis.
$S D S-P A G E$ - Storage proteins were analyzed by vertical $17.68 \%$ SDS-PAGE with Tris-borate buffer system for migration (SHEWRY et al., 1978), modified to $5 \%$ stacking gel and 29 acrilamide: 1 bis for the running gel. Migration occurred during $19 \mathrm{~h}$ in a $4^{\circ} \mathrm{C}$ cold chamber. The gels were stained with Coomassie brilliant blue R-250, according to GEPTS et al. (1992). The molecular weight markers myosin $(200 \mathrm{KDa})$, phosphorylase $\mathrm{b}(97.4 \mathrm{KDa})$, bovine serum albumine (66 KDa), ovalbumin (46 KDa), carbonic anhydrase (30 $\mathrm{KDa})$, trypsin inhibitor (21.5 KDa) e lysozyme (14.3 $\mathrm{KDa}$ ) were used from Amersham Pharmacia.

Gel analysis - Gel images were taken using a Densitometer and analyzed by Molecular Analyst Fingerprinting software (Bio-Rad, USA). The obtained data comprised the presence or absence of each analyzed band, not including quantitative differences among trees.

Statistical analyses - The intrapopulational genetic variability and the genetic divergence degree among populations were estimated by the similarity Jaccard's coefficient (JACCARD, 1908), calculated among 168 trees in pairs. Shannon information measure (LEWONTIN, 1972) was used to estimate the total genetic diversity of the species and its partition into the within- and between-populations values. To analyze the relationships among the trees, a phenogram was obtained based on King's distances (KING et al., 1993) and clustered by NeighborJoining using the software Treecon.

\section{RESULTS AND DISCUSSION}

In this study, 80 different bands of proteins were identified in the species. To facilitate the analysis, the studied area of each gel was divided into three regions, as shown in table 1 . More than $70 \%$ of the analyzed bands weighted less than $46 \mathrm{KDa}$ and most of them less than $30 \mathrm{KDa}$. A total of 16 bands $(20 \%)$ occurred in less than $10 \%$ of all trees. Three of them were reported only in trees of PR, and the remaining 13 in at least two of the four populations.

Storage proteins from maté disclosed high variability within-population. Each of 168 analyzed trees presented an unique protein pattern. Although, the four populations shared $65(81 \%)$ of the 80 analyzed bands (Table 1), this high variability can be understood since the frequencies of each band varied greatly among the populations. The frequency of shared polypeptide chains seems to be independent of molecular weight classes. On average, $78 \%$ of bands occurred in less than half trees. Only three bands were present in more than $90 \%$ of all trees, two of them being ubiquitous. 


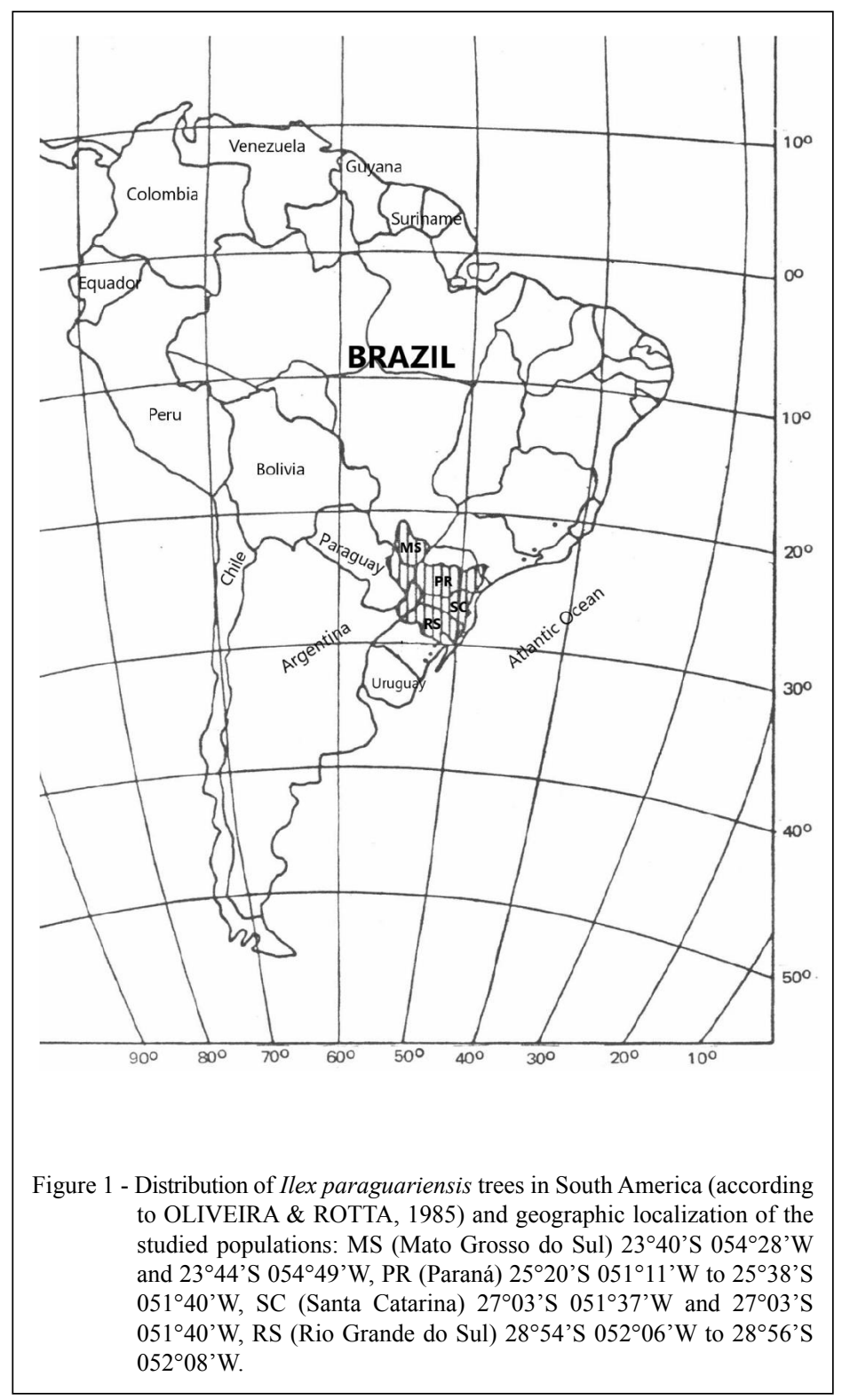

The total number of bands detected in each population ranged from 70 , in the MS population, to 77 in PR (Table 1). Only three low frequency bands, all from PR, are exclusive bands. The number of bands per tree ranged from 16 to 43, both limits being reported in RS trees. There seemed to be a slight difference between the two marginal populations (MS and RS) and the two more central populations (PR and SC), in which $70 \%$ or more bands per population occurring in less than half of trees. The two more central had a higher percentage of common bands occurring in more than $50 \%$ of the sample.
The Jaccard's similarity coefficient showed that the populations averages varied from $\bar{S}_{J}$ $=0.348$, for the PR population, to $\bar{S}_{J}=0.412$ for that of MS. As expected from the occurrence of common bands in each population, it seems that PR, SC, and also RS present higher intrapopulational variability than MS. On average, every two trees of the last population share $41.2 \%$ of their bands; in other words, on average any two trees of maté differ in almost $60 \%$ of their polypeptide chains. Shannon estimates for each population $\left(H_{o}\right)$ varied from 0.218 for MS to 0.264 for RS. The geographic intermediate 
Table 1 - Number of polypeptide eletroforetic bands in each gel region and their occurrence (in \%) in each frequency class for the whole sample; number of bands shared by the four populations. Number of total bands per population and their occurrence (in \%) in each frequency class; number of unique bands in each population.

\begin{tabular}{|c|c|c|c|c|c|c|c|}
\hline \multirow[t]{2}{*}{ Gel region } & \multirow[t]{2}{*}{$\begin{array}{c}\text { Range of molecular } \\
\text { weight }\end{array}$} & \multirow[t]{2}{*}{$\begin{array}{l}\text { Number of } \\
\text { bands }\end{array}$} & \multicolumn{4}{|c|}{------------Frequency of bands in the sample--------- } & \multirow[t]{2}{*}{$\begin{array}{l}\text { Number of shared } \\
\text { bands }\end{array}$} \\
\hline & & & $90 \%$ & $<90-50 \%$ & $<50-10 \%$ & $<10 \%$ & \\
\hline I & $>220-46 \mathrm{KDa}$ & 23 & 9 & 13 & 56 & 22 & 19 \\
\hline II & $<46-30 \mathrm{KDa}$ & 23 & 0 & 22 & 56 & 22 & 18 \\
\hline III & $<30-\leq 21.5 \mathrm{KDa}$ & 34 & 3 & 20 & 59 & 18 & 28 \\
\hline TOTAL & & 80 & 4 & 18 & 58 & 20 & 65 \\
\hline \multirow{2}{*}{\multicolumn{2}{|c|}{ Population (State) }} & $\begin{array}{l}\text { Number of } \\
\text { bands }\end{array}$ & \multicolumn{4}{|c|}{----------Frequency classes in each population------- } & $\begin{array}{c}\text { Number of unique } \\
\text { bands }\end{array}$ \\
\hline & & & $90 \%$ & $<90-50 \%$ & $<50-10 \%$ & $<10 \%$ & \\
\hline MS & & 70 & 9 & 21 & 50 & 20 & 0 \\
\hline PR & & 77 & 4 & 14 & 60 & 22 & 3 \\
\hline $\mathrm{SC}$ & & 72 & 4 & 19 & 63 & 14 & 0 \\
\hline RS & & 75 & 7 & 25 & 55 & 13 & 0 \\
\hline
\end{tabular}

MS: Mato Grosso do Sul, PR: Paraná, SC: Santa Catarina, RS: Rio Grande do Sul.

populations presented intermediate values $(\mathrm{PR}=0.262$ and $\mathrm{SC}=0.255$ ). The average value for the four populations was $H_{p o p}=0.250$, representing $95 \%$ of the whole species diversity $\left(H_{s p}=0.264\right)$.

The similarity among all trees can be observed in figure 2, and five larger clusters can be recognized (see arrows). Most trees of each population joined in one of the two largest clusters (No. 1 and 2). Cluster 1 comprises $70 \%$ of all trees from MS and $51 \%$ of those from PR. Cluster 2 includes $49 \%$ of the trees from SC and $54 \%$ of those from RS. The remaining trees are reported in clusters 3 to 5 . It seems that, in spite of the observed high intrapopulational variability, most trees from the same population still show some degree of similarity among themselves.

The same populations and in most cases the same trees were analyzed at DNA level using RAPD markers by GAUER \& CAVALLI-MOLINA (2000). As for proteins, no two trees shared the same DNA band pattern. Average coefficients of Jaccard for each population showed the same level of diversity as observed for storage proteins. However, Shannon measure of diversity represented $85 \%$ of the total diversity of maté, indicating that RAPD patterns show somewhat lower intrapopulational variability than storage protein profiles. The phenogram also supports that conclusion. WINGE et al. (1995) reported a high average heterozygosity in esterases and acid phosphatases systems in Ilex populations, and a large amount of morphological variation was reported among Ilex trees (EDWIN \& REITZ, 1967, GIBERTI, 1979, WINGE et al., 1995, COELHO et al., 2002). In antioxidant activity and in triterpene saponins, caffeine, theobromine and chlorogenic acid contents, significant differences among progenies were verified by NAKAMURA et al. (2009).

All approaches used to analyze the species disclosed high variability within-population. The high intrapopulational variability observed could be expected since maté is a long-living tree, has obligate cross-fertilization, occupies a fairly large geographic area, has $2 \mathrm{n}=40$ chromosomes and seeds seem to be dispersed by birds (that ingest fruits). Genetic diversity among geographic populations of a species is the first step to their evolutionary divergence. The study of different populations of a species allows obtaining information about the evolutionary forces that possibly produced the observed divergence.

Based on Jaccard's coefficient, the average similarity ranged from 0.341 , between $\mathrm{PR}$ and $\mathrm{SC}$, to 0.364 for MS and PR. These coefficients indicate two important aspects: a) only about $35 \%$ of all polypeptide chains are shared, on average, between trees of any two populations, what does not seem different from what is observed within populations. Nevertheless, the gross average coefficients, $\bar{S}_{J}$ intra $=0.374$ and $\bar{S}_{J}$ inter $=0.308$, show almost $7 \%$ of difference; b) there is an absence of correlation between geographic distances and degree of similarity 


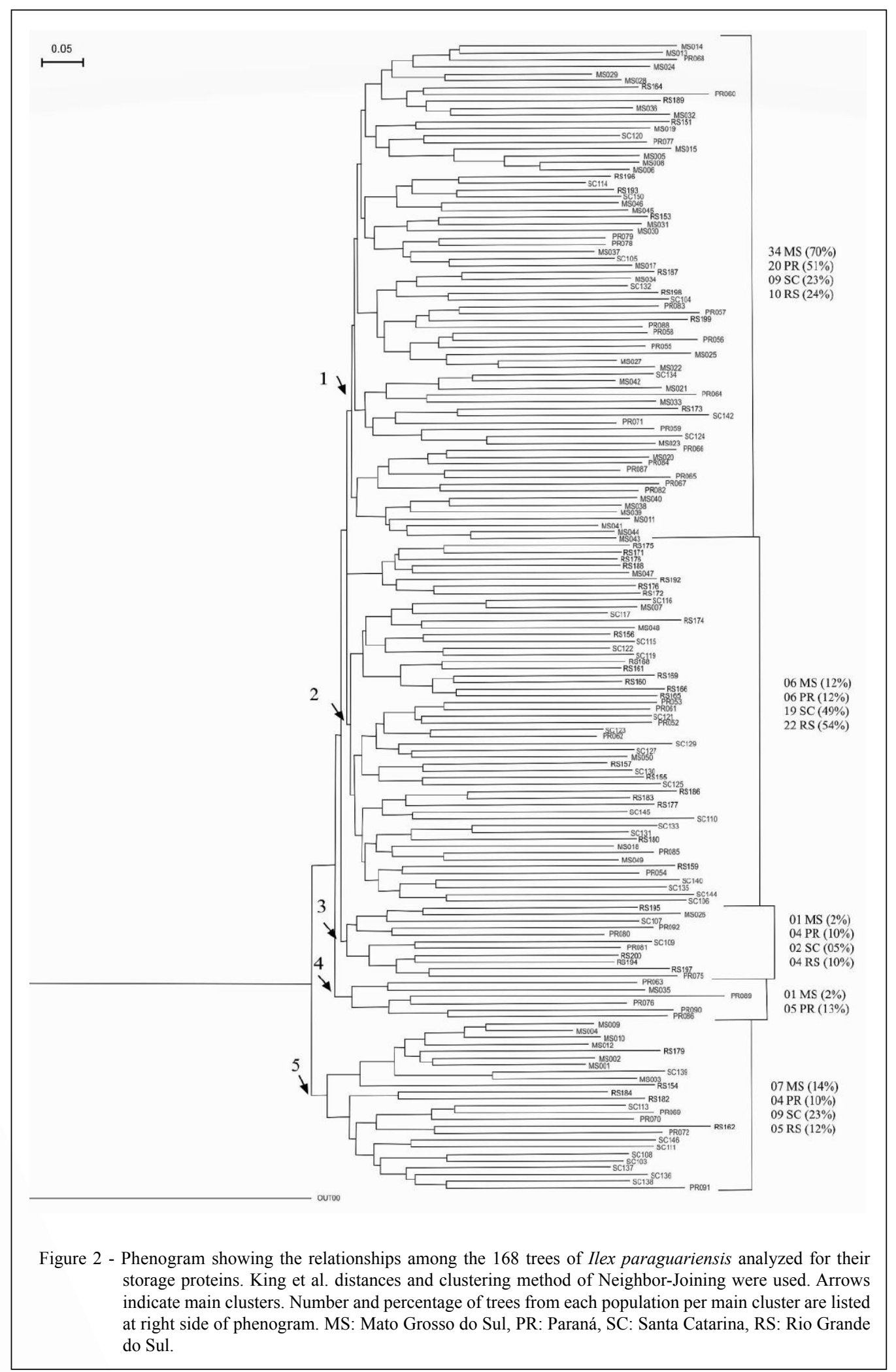

Ciência Rural, v.49, n.2, 2019. 
in shared storage protein polypeptide chains. Shannon measure disclosed that only $5 \%$ of the total diversity is contributed by the diversity between-populations. These data suggested a high uniformity in storage protein patterns indicating low diversity among populations. Conversely, the comparisons among the four populations showed that MS population presents about 15 to $17 \%$ less variability withinpopulation than the three populations from the Southern Brazilian Region. Some interpopulational divergence in seed protein bands can also be observed in phenogram of figure 2 . As already pointed out, one of the main clusters (No. 1) joined $70 \%$ of the trees from MS and 51\% from PR, besides some others of the remaining populations. Forty nine percent of trees from $\mathrm{SC}$ and $54 \%$ from RS are reported in cluster 2. The preferential clustering of the two northern populations and, in another cluster, the two southern ones suggested some geographic differentiation.

Results from RAPD markers obtained by GAUER \& CAVALLI-MOLINA (2000) for the same populations showed that $15 \%$ of the whole species diversity is due to component between-populations. The clustering of trees on the storage protein phenogram supports the indications of some differentiation among populations. The same four populations were also analyzed for their xanthines, mainly caffeine and theobromine content. The highest concentrations of caffeine were found in trees from MS, the northernmost population, and a gradient of decreasing concentrations was observed towards the South. The opposite gradient was observed for theobromine. Similarly, a north-south decreasing gradient in the maximum stage of embryo development was reported by WINGE et al. (1995).

Summing up, different analyses using different approaches, disclosed high intrapopulational variability, but depending on the approach, a north to south gradient or at least a small trend toward geographic differentiation could be observed between populations. Storage protein patterns seem to present the highest within-population variability and the lowest between-populations diversity, followed by DNA patterns obtained by RAPD, by isoenzymes and by content of the secondary metabolites caffeine and theobromine. This would be expected for a species such as maté, dioecious, pollinated mostly by insects but also by wind (FERREIRA et al., 1983) and with their seeds dispersed by birds. It is important to emphasize that whole populations are located in the main distribution area of I. paraguariensis, none of them were located in the extreme southern or northern marginally isolated areas of the species. The very high variability within-population and low diversity between-populations observed for storage proteins among populations, some of them fairly distant, inhabiting regions with different climates, suggest the homogenizing effect of gene flow. Conversely, the existence of gradients could be interpreted as the result of selection acting on allopatric populations.

In the last 30 to 40 years, the advance of agriculture to the West-Central regions of Brazil, especially for cultivation, has increasingly reduced the main distribution area of wild maté, with the consequent fragmentation of which possibly was a more continuous area in the past. In the future, this fragmentation can cause a high divergence among the recently fragmented populations of the species. Nevertheless, it seems that it did not yet affect the species diversity, possibly because maté is a fairly long-living species that can reach one hundred years of age. At least part of the sampled trees may be representatives of a generation of trees that was established well before the agricultural impact caused by the ongoing fragmentation of maté distribution area.

\section{ACKNOWLEDGEMENTS}

Thanks to Maté Industries (Santo Antônio Ind. Com. Exp. de Alimentos Ltda-MS, Fazenda Mate Amargo-MS, ErvaMate Schier Ind. Com. Ltda-PR, Ervateira Regina Ltda-SC and Ximango Indústria de Erva-Mate-RS), and Prefeitura Municipal de Ilópolis-RS for allowing the harvest of plant material. Thanks to Dr Diógenes Santos, Dr José Procópio Senna and $\mathrm{Dr}^{\mathrm{a}}$ Cinara Echart for technical assistance, $\mathrm{Dr}^{\mathrm{a}}$ Luciane Gauer for helpful discussions and special thanks to Dr Arthur G. Fett-Neto for critical reading. Financial support by funding agencies Conselho Nacional de Desenvolvimento Científico e Tecnológico (CNPq) and Fundação de Amparo à Pesquisa do Estado do Rio Grande do Sul (FAPERGS) is gratefully acknowledged.

\section{DECLARATION OF CONFLICTING INTERESTS}

The authors declare no conflict of interest.

\section{AUTHORS' CONTRIBUTIONS}

The authors contributed equally to the manuscript.

\section{REFERENCES}

BRACESCO, N. et al. Antioxidant activity of a botanical extract preparation of Ilex paraguariensis: prevention of DNA doublestrand breaks in Saccharomyces cerevisiae and human low-density lipoprotein oxidation. Journal of Alternative and Complementary Medicine, v.9, n.3, p.379-387, 2003. Available from: <https://www. ncbi.nlm.nih.gov/pubmed/12816626>. Accessed: Sept. 7, 2018. doi: $10.1089 / 107555303765551606$.

COELHO, G.C. et al. Populational diversity on leaf morphology of maté (Ilex paraguariensis A. St.-Hil., Aquifoliaceae). Brazilian Archives of Biology and Technology, v.45, n.1, p.47- 
51, 2002. Available from: <http://dx.doi.org/10.1590/S151689132002000100008>. Accessed: Sept. 7, 2018. doi: 10.1590/ S1516-89132002000100008.

COSTA, D.E.M. et al. Antimicrobial activity of yerba mate (Ilex paraguariensis) extract against microorganisms isolated from chicken meat. Ciência Animal Brasileira, v.18, p.1-7, e-42254, 2017. DOI: $10.1590 / 1089-6891 v 18 \mathrm{e}-42254$. Available from: $<\mathrm{http}: / /$ dx.doi.org/10.1590/1089-6891v18e-42254>. Accessed: Sept. 7, 2018. doi: 10.1590/1089-6891v18e-42254.

EDWIN, G.; REITZ, P.R. Aquifoliáceas. In: REITZ, P.R. Flora ilustrada catarinense. I parte. Fasc. Aqui. Itajaí, Herbário Barbosa Rodrigues/CNPq, 1967. p. 27-34. Available from: $<$ http:// ainfo.cnptia.embrapa.br/digital/bitstream/item/101126/1/PA-1983Oliveira-AreaDistribuicao.pdf.pdf > . Accessed: Sept. 7, 2018.

FAGUNDES, A. et al. Ilex paraguariensis: compostos bioativos e propriedades nutricionais na saúde. Revista Brasileira de Obesidade, Nutrição e Emagrecimento, São Paulo, v.9, n.53, p.213-222. 2015. Available from: <http://www.rbone.com.br/ index.php/rbone/article/view/394>. Accessed: Sept. 7, 2018.

FERREIRA, A.G. et al. Proporção de sexo e polinização em Ilex paraguariensis St. Hil. Brasil Florestal, v.53, p.29-33, 1983. Available from: $<$ https://core.ac.uk/download/pdf/45482026.pdf $>$. Accessed: Sept. 7, 2018

GAUER, L.; CAVALLI-MOLINA, S. Genetic variation in natural populations of maté (Ilex paraguariensis A. St.-Hil., Aquifoliaceae) using RAPD markers. Heredity, v.84, n.6, p.647656, 2000. Available from: <https:/www.ncbi.nlm.nih.gov/ pubmed/10886380>. Accessed: Sept. 7, 2018. doi: 10.1046/j.13652540.2000 .00687 .

GEPTS, P. et al. Analysis of seed proteins, Isozymes, and RFLPs for genetic and evolutionary studies in Phaseolus. In: LINSKENS, H.-F.; JACKSON, J.F. Moderns methods of plant analysis. New series. Berlin : Springer, 1992. p.63-93. Available from: <https:// link.springer.com/chapter/10.1007/978-3-662-01639-8 4>. Accessed: Sept. 7, 2018. doi: 10.1007/978-3-662-01639-8_4.

GIBERTI, G.C. Las especies argentinas de genero Ilex L (Aquifoliaceae). Darwiniana, v.22, n.1-3, p.217-240, 1979. Available from: <https://www.jstor.org/stable/23216499> Accessed: Sept. 7, 2018.

GOLDENBERG, D. Maté: a risk factor for oral and oropharyngeal cancer. Oral Oncology, v.38, p.646-649, 2002. Available from: $<$ https://doi.org/10.1016/S1368-8375(01)00127-0>. Accessed: Sept. 7, 2018. doi: 10.1016/S1368-8375(01)00127-0.

GONZALEZ DE MEJIA, E. et al. Effect of yerba mate (Ilex paraguariensis) tea on topoisomerase inhibition and oral carcinoma cell proliferation. Journal of Agricultural and Food Chemistry, v.53, n.6, p.1966-1973, 2005. Available from: <https://www.ncbi. nlm.nih.gov/pubmed/15769122>. Accessed: Sept. 7, 2018. doi: $10.1021 / \mathrm{jf0} 48158 \mathrm{~g}$.

GOSMANN, G. et al. A new saponin from mate, Ilex paraguariensis. Journal of Natural Products, v.52, p.1367, 1989. Available from: <https://pubs.acs.org/doi/abs/10.1021/np 50066a036? journalCode $=$ jnprdf $>$. Accessed: Sept. 7, 2018. doi: $10.1021 / \mathrm{np} 50066 \mathrm{a} 036$

GRONDONA, E. M. História de la yerba mate. II. Sinonimia, cariología y distribución geográfica. Revista Argentina de
Agronomía, v.21, p.9-24, 1954. Available from: <http://www. fao.org/tempref/GI/Reserved/FTP_FaoRlc/old/prior/segalim/ prodalim/prodveg/cdrom/contenido/libro09/Cap4_7.htm>. Accessed: Sept 7, 2019

GUGLIUCCI, A. Antioxidant effects of Ilex paraguariensis: induction of decreased oxidability of human LDL in vivo. Biochemical and Biophysical Research Communications, v.224, n.2, p.338-344, 1996. Available from: <https://www.ncbi. nlm.nih.gov/pubmed/8702392>. Accessed: Sept. 7, 2018. doi: $10.1006 /$ bbrc. 1996.1030 .

GUGLIUCCI, A.; STAHL, A. J. Low density lipoprotein oxidation is inhibited by extracts of Ilex paraguariensis. Biochemistry and Molecular Biology International, v.35, n.1, p.46-56, 1995. Available from: <https://www.ncbi.nlm.nih. gov/pubmed/7735139>. Accessed: Sept. 7, 2018. doi: 10399712/95/010047-10S45.00/0.

JACCARD, P. Nouvelles recherches sur la distribution florale. Bulletin de la Société Vaudoise des Sciences Naturelles, v.44, p.223-270, 1908. Available from: <https:/www.scirp.org/ (S(i43dyn45teexjx455q1t3d2q))/reference/ReferencesPapers. aspx?ReferenceID $=1222324>$. Accessed: Sept. 7, 2018. doi: $10.5169 /$ seals-268384.

KING, G. et al. Genetic similarity among ecotypes of Arabidopsis thaliana estimated by analysis of restriction fragment length polymorphisms. Theoretical and Applied Genetics, v.86, p.1028-1031, 1993. Available from: <https://link.springer.com/ article/10.1007/BF00211057>. Accessed: Sept. 7, 2018. doi: 10.1007/BF00211057.

LEWONTIN, R.C. The apportionment of human diversity. In: DOBZHANSKY, T. et al. Evolutionary biology. New York : Appleton-Century-Crofts, 1972. v.6, p.381-398. Available from: $<$ https://doi.org/10.1007/978-1-4684-9063-3_14>. Accessed: Sept. 7, 2018. doi: 10.1007/978-1-4684-9063-3_14.

MCDANIEL, R.G. Electrophoretic characterization of proteins in Hordeum. Journal of Heredity, v.61, p243-247, 1970. Available from: <https://doi.org/10.1093/oxfordjournals.jhered. a108093>. Accessed: Sept. 7, 2018. doi: 10.1093/oxfordjournals. jhered.a108093.

NAKAMURA, K.L. et al. Genetic variation of phytochemical compounds in progenies of Ilex paraguariensis St. Hil. Crop Breeding and Applied Biotechnology, v.9, p.116-123, 2009. Available from: <http://www.sbmp.org.br/cbab/siscbab/uploads/ c8eb9791-e4cc-9ef6.pdf>. Accessed: Sept. 7, 2018.

OLIVEIRA, Y.M.M.; ROTTA, E. Área de distribuição natural de erva-mate (Ilex paraguariensis St. Hil.). Anais do X Seminário sobre atualidades e perspectivas florestais: silvicultura da ervamate. Curitiba: Embrapa/IBDF, 1985. p. 28. Available from: <http:// ainfo.cnptia.embrapa.br/digital/bitstream/item/101126/1/PA-1983Oliveira-AreaDistribuicao.pdf.pdf $>$. Accessed: Sept. 7, 2018.

RICCO, R.A., et al. Estudio comparativo de flavonoides en especies austrosudamericanas del genero Ilex. In: WINGE, H. et al. Ervamate: biologiaecultivonoconesul.EditoradaUniversidade/UFRGS, Porto Alegre, 1995. p.243-249. Available from: <http://www. scielo.br/scielo.php?script $=$ sci_nlinks\&ref $=000090 \&$ pid $=$ S15160572200900010000900017\&lng=pt $>$. Accessed: Sept. 7, 2018.

SCHINELLA, G. et al. Cardioprotective effects of Ilexparaguariensis extract: evidence for a nitric oxide-dependent mechanism. Clinical

Ciência Rural, v.49, n.2, 2019. 
Nutrition, v.24, n.3, p.360-366, 2005. Available from: <https:// www.ncbi.nlm.nih.gov/pubmed/15869828>. Accessed: Sept. 7, 2018. doi: 10.1016/j.clnu.2004.11.013.

SHEWRY, P.R. et al. A comparison of methods for the extraction and separation of hordein fractions from 29 barley varieties. Journal of the Science of Food and Agriculture, v.29, p.433-441, 1978. Available from: <https://doi.org/10.1002/jsfa.2740290505>. Accessed: Sept. 7, 2018. doi: 10.1002/jsfa.2740290505.

SINGH, A.K. et al. Phylogenetic relations in Section Arachis based on seed protein profiles. Theoretical and Applied Genetics, v.82, p.593-597, 1991. Available from: <https://doi. org/10.1007/BF00226795>. Accessed: Sept. 7, 2018. doi: 10.1007/ BF00226795.
SINGH, A.K. et al. Phylogenetic Relationship in the genus Arachis based on seed protein profiles. Euphytica, v.74, p.219-225, 1994. Available from: <https://doi.org/10.1007/ BF00040404>. Accessed: Sept. 7, 2018. doi: 10.1007/ BF00040404.

WINGE, H. et al. Variabilidade genética em populações nativas de erva-mate e a implantação de bancos de germoplasma. In: WINGE, $\mathrm{H}$ et al. Erva-mate: biologia e cultivo no cone sul. Editora da Universidade/UFRGS, Porto Alegre, 1995. p.323-345. Available from: <http://www.scielo.br/ scielo.php?script $=$ sci_nlinks \& ref $=000068 \&$ pid $=$ S0 103 $8478200200030000800010 \& \operatorname{lng}=$ pt $>$. Accessed: Sept. 7, 2018. 